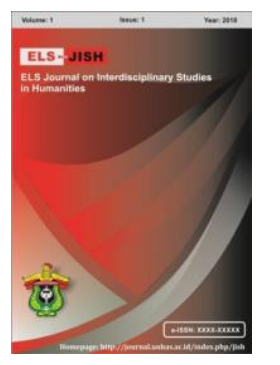

ELS-JISH

ELS Journal on Interdisciplinary Studies on Humanities

Volume 3 Issue 3, 2020

ISSN (print) : 2621-0843

ISSN (online) : 2621-0835

Homepage : http://journal.unhas.ac.id/index.php/jish

\title{
Shifting Among The Noble Teenagers of Mambalan Village Gunung Sari
}

\author{
Zainudin Abdussamad ${ }^{1}$, Hamzah A. Machmoed ${ }^{2}$, \\ Abidin Pammu ${ }^{3}$, Harlinah Sahib ${ }^{4}$ \\ 1ssamadzain12@gmail.com
}

\begin{abstract}
This study aims to reveal the phenomenon of language shift among the noble teenagers of mambalan Village. Research has been carried out with the noble teenagers as the participants of this research. To improve understanding of the complexity of this research, this research used descriptive qualitative method by using some tools in collecting the data such as, questionnaires, interview, data recording, note taking and observation. After obtaining the data, the data analyzed by Gathering and understanding data transcription carefully, coding the data transcription word per word and displaying the words into the relevant conversation. The study found that there is language shift occurred among the noble teenagers of mambalan village. The finding is strengthened by vocabularies and sentences which shifted from high Sasak language to low Sasak language.
\end{abstract}

Keywords: Shifting, Noble, Mambalan village

How to cite: Abdussamad, Z., et al. (2020). Shifting Among The Noble Teenagers of Mambalan Village Gunung Sari. ELS Journal on Interdisciplinary Studies in Humanities, 3(3), 425-432. DOI: https://doi.org/10.34050/elsjish.v3i3.11304

\section{Introduction}

Indonesia consists of many tribes with their own different local languages. The diversity of local language of Indonesia is one of the uniqueness and characterization of Indonesia as a rich country. A local language is a language used in an existing region where a country has a smaller area than that country and only used by the residents that occupy the area. Because of the use of local language only by the residents who live in the smaller area than that country, so the local language is called as vernacular or traditional language. Bugis Language, for instance, is one of the example of traditional languge that uses in Bulukumba Regency, South Sulawesi Province (Rahman et al., 2019).

The use of vernacular language can be found in many places in Indonesia such as Mambalan. Mambalan is a small village which lies at Gunung Sari West Lombok West Nusa Tenggara. Mambalan village populated by the member of aristocracy and ordinary class. Although they have different status but they can live together side by side in peace. This condition makes Mambalan popular as

${ }^{1,2,3,4}$ Universitas Hasanuddin, Indonesia 
the unique village and people outside of Mambalan village call Mambalan as the "daerah kedatuan" (the area of royal family).

According to the data taken at the village office, the total wide of Mambalan village only is 333. 45 hectares and inhabited by the 2150 total populations. From the total population, the number of the member of aristocracy who populated Mambalan village only $21 \%$ or 451 population. This number is relatively small compared to the ordinary class. Further, according to the data taken at village office, most of these member of aristocracy live as farmers and construction workers.

In communicating to each other in their daily life, Mambalan society use local language which is called Sasak language which divided into two levels named high Sasak language and low Sasak language. Besides speaking sasak language, Mambalan society also use Bahasa Indonesia especially when communicate with the strangers and in formal situation.

The condition above is really contradictive compared to the condition when most of the members of aristocracy commonly use the high language when they communicate to each other. Further, from the small interview especially with some of the noble teenagers, they said that they prefer use the low Sasak language and Bahasa Indonesia to high Sasak language when they interact to each among the member of aristocracy and the ordinary class. They never paid attention much to their status and the language they should use.

Concern to the language used by member of aristocracy especially by the noble teenagers above, the noble teenagers seem tend to be shifted from the high Sasak language to low sasak language. The condition of move away from one language to other language is popular with the term of language shift.

Further, language shift is the process by which a speech community in a contact situation (i.e. consisting of bilingual speakers) gradually stops using one of its two languages in favor of the other.

According to Fasold, language shift simply means that a community gives up a language completely in favour of another one (Fasold, 1987:213). Fasold also states that language shift sometimes is dramatically referred to as language death, which occurs when a community totally shifts away from using its own language to a new language. Language maintenance on the other hand is said to be "often a characteristic of bilingual or multilingual communities". This is said because multilingual communities are believed to be maintaining each language for certain domains with little encroaching of each language on other domains (Fasold, 1987: 213).

Further about the language shift. According to Fishman, language shift is also known as a movement away from the ethnic language in which this phenomenon is seen as a noticeable change in the habitual use of a language. (Fishman, 1968:424). Related to the language shift and the language use by the noble teenagers of Mamabalan village above, the writer temporary observation found that there is language shift occured among the noble teenagers of Mambalan village from high Sasak to low Sasak language. 
Depart from the condition above, the writer is interested in investigating the language shift phenomenon especially among the teenagers of mambalan village.

For the better understand language use and language shift among the noble teenagers of Mambalan village, this study addresses the questions how the language shift and what vocabularies tend to be shifted from high Sasak language to low Sasak language.

\section{Objective of Study}

The objective of this study is to find out the language shift phenomenon from high Sasak language to low Sasak language among the noble teenagers of Mambalan village

\section{Methodology}

This research used descriptive qualitative method. Descriptive qualitative approach is essential to improve understanding of the complexity of this research especially to improve language shift among the Member of aristocracy of Mambalan village. The data taken allowed the writer to determine and analyze the occurring of language shift among the noble teenagers of Mambalan village

\subsection{Participants}

The samples of the data taken from the 50 noble teenagers who really native and domicile in Mambalan village by the age 15 to 18 years old. The selection of noble teenagers as the subject of this research departed from the assumption that because of the development of technology and information make the teenagers tent to follow the trends which influence to the language they use.

\subsection{Procedures}

In collecting the sufficient data which is very essential for this research, the writer collected the data by using some tools. Firstly, the writer distributed the questionnaires which contain of the main questions related to the status of them in that society (member of aristocracy or ordinary class), and the language that they used when interact each other (the high Sasak language or low Sasak.

Secondly, the writer conducted interview. The writer visited each of the family of member of aristocracy house and clearly explained the interview questions before the interview started. The participants were assured that the information would solely be used for the research. The interview recorded and took time for about 20 minutes each interview. The questions of the interview only focused on the used of high Sasak language and low Sasak language.

Thirdly, the writer recorded the conversation which conducted by the participants in this case by the noble teenagers.

Recording is needed not only for saving the content of conversation between the writer and the participants but also for helping the writer in analyzing the content of the conversation.

Fourth, the writer takes note in every activities during did the research. 
Taking note is needed in this research because by taking note the writer could see the gesture and the body language of the participants which supported the result of the recording.

Fifth, the writer observed the process of the research massively from the beginning to the end of the process of this research. By observation, the writer knew the progress of the research in order to be able to correct and make this research to be better.

\subsection{Analysis}

After obtaining the data, the researcher analyzed the data by Gathering and understanding data transcription carefully, Coding the data transcription word per word and displaying the words into the relevant conversation.

\section{Results and Discussion}

After doing the research, the writer found that there are some words tend to be shifted from high Sasak language to low Sasak language which is used by the noble teenagers of mambalan village. The vocabularies tend to be shifted can be seen from the table below:

Table 1. Vocabularies tend to be shifted from high Sasak language to low Sasak language

\begin{tabular}{lll}
\hline \multicolumn{1}{c}{ High variety } & \multicolumn{1}{c}{ Low Variety } & Meaning \\
\hline Sampun & Wah & Already \\
\hline kayun & Mele & Want \\
\hline nggih & Aok & Yes \\
\hline nenten & Ndek & No \\
\hline Tiang & Aku & I \\
\hline Sai & Sai & Who \\
\hline Napi & Ape & what \\
\hline Nenten & Ndekman & Not yet \\
\hline Seriuk & Gitak & see \\
\hline Serminang & Engat & see \\
\hline mangkin & Bareh & later \\
\hline lemak & Jemak & tomorrow \\
\hline Mangkin & Neke & now \\
\hline Nggih & Ndih & yes \\
\hline Sampun & Sawek & finish \\
\hline piringan & Dengahin & listen \\
\hline Mbe lumbar & Bak embe & Where do you go \\
\hline Piran & Piran & when \\
\hline telas & Buek & Finish up \\
\hline Sopok & Sekek & one \\
\hline bau & Bau & can \\
\hline piran & Piran & when \\
\hline Arak napi & ye kembeK & What happen \\
\hline nenten & Ndarak & nothing \\
\hline daye & Daye & south \\
\hline & & \\
\hline
\end{tabular}


Zainudin Abdussamad. 3(3): 425-432

\begin{tabular}{lll}
\hline enten & Arak & There is \\
\hline lupak & Lupak & forget \\
\hline Kayun & Mele & want \\
\hline Mankin & Nengke & now \\
\hline ngonek & Onek & Just now \\
\hline petak & Pete & Look for \\
\hline mbe & Mbe & Where is \\
\hline Nike & Tiye & Here is \\
\hline toloq & Tolok & put \\
\hline Mesare & Tindok & sleep \\
\hline Gedeng & Bale & house \\
\hline sede & Saor & broken \\
\hline Kawih & Kadu & Use \\
\hline sekecik & Sekedik & little \\
\hline selapuan & Selapuk & all \\
\hline mangkin & Bareh & later \\
\hline
\end{tabular}

The examples of the use of the shifted vocabularies above can be seen from the conversation below:

The examples of the use of the shifted vocabularies above can be seen from the conversation below:

Conversation 1.

$$
\begin{aligned}
& \text { Irwan :Bak embe? } \\
& \text { Father } \quad \text { : Bak tau jamaah haji lek buwuh. } \\
& \text { Irwan } \quad \text { : Oo lek buwuh no. }
\end{aligned}
$$

\section{Piran lalo bak buwuh?}

Father: Bareh amun payu.

The conversation above took place at the living room and involves father, and son. The son (16 Years old named Irwan) asked his father about where does his father go, the son asked by using low variety by saying "bak mbe" which means "where do you go?" And answered by his father by using low variety too by saying "bak tau Jamaah haji lek Buwuh". Should be as the member of aristocracy the son should use high Sasak language when talked to his father by saying"mbe lumbar?

Further, his son says "piran lalo bak buwuh?" Which means "when do you go to Buwuh?" and answered by his father by saying "bareh amun payu". Which means "later".

Both of the statements are low variety. Should be as the member of aristocracy the son should use high Sasak language by saying "Piran side lumbar tipak Buwuh?" From the conversation we know that language shift happen from high Sasak language to low Sasak language which conducted by the noble teenagers of Mambalan village.

Conversation 2

Irwan : Mbe lek de tindok? Engak ndek tindok lek bale? 
Supardi: ni lek tende.

The conversation is conversation between two brothers. The conversation took place at the living room. The two brothers talked about place to sleep after the earthquake. Brother 1 (Irwan 16 Years old) asks his brother "Mbe lek tindok? Engak ndek tindok lek bale?" which means "Where do you sleep?, why do not sleep at home? The brother 2 (Supardi 18 years old) answered the questions by using low Sasak variety by saying "ni lek Tende, Which means "I sleep at ten,. Should be as the member of aristocracy the two brothers should use high sasak language variety. The brother 1 should say "mbe taok side mesare? "Sampun napi nenten mesare elek gedengan?" And brother 2 should answer "nike elek tende"

The conversation above showed that the two brothers did not paid attention to their status as the member of aristocracy. They shifted from high Sasak language to low Sasak language.

Conversation 3

$$
\text { Nisa : be kadu ku sandel baruk ne? }
$$

The conversation above is conversation involved sister and brothers. The conversation took place at the terrace and they talked about the coming of the sister from her house. When the sister (Nisa 19 Years old) wanted to go home she looked for her sandals. She looked for her sandals and asked her brother 1 (Said 17 Years old) by using low Sasak language variety by saying "mbe kadungku sandel baruk ne?" which means " which ones slippers I wore just now?" The brother 1 said by using low Sasak language variety too by saying " ye bireng kadu sandel tiye' which means "you wore the black sandals."

Should be as the member of aristocracy the sister should use high sasak language variety by saying "alas cokor mbe tiang kawih baru". The brother 1 also should use high Sasak variety when answers his sister by saying "Ye bireng kawih de".

The conversation above showed that there sister and brother above shifted from high Sasak language to low Sasak language. They never paid attention to their position in the family and their status as the member of aristocracy.

\section{Conclusion}

Based on the results and discussion above, the writer concluded that, when communicated to each other in daily interaction most of the noble teenagers of Mambalan village used low Sasak language not only with the same age but also with the elders. From this condition can be also concluded that there is language shift phenomenon happened from high Sasak language to low Sasak language among the noble teenagers of mambalan village. The language shift phenomenon can be seen from the vocabularies which they used in daily interaction. We recommend to the next researcher to find out the factors which influence the occurring of language shift among the noble teenagers of Mambalan village. By finding the factors of the occurring of the language shift, 
we can help to the Mambalan society especially the member of aristocracy of Mambalan village to maintain the high Sasak language in order to avoid language endangered.

\section{References}

Bosch, B. \& de Klerk, V. (1998). Afrikaans to English: A case study of language shift. South-African Journal of Linguistics 16(2):43-51.

de Vries, J. (1992). Language maintenance and shift: Problems of measurement. In Maintenance and loss of minority languages, ed. W. Fase, K. Jaspaert, and S. Kroon, 211- 222. Amsterdam: John Benjamins.

Dow, J. R., ed. 1991. Language and ethnicity 2. Amsterdam: John Benjamins.

Eckert, P. 2000. Linguistic variation as social practice. Malden, Mass: Blackwell Publishers.

Fase, W. Jaspaert, K. Kroon, S. 1992 Maintenance and Loss of Minority Languages: Introductory Remarks. In Fase, W. Jaspaert, K Kroon, S. (eds.), Maintenance and loss of minority languages, AmsterdamPhiladelphia, John Benjamins Publishing Company.

Fishman, J. A. 1989. Language \& Ethnicity in Minority Sociolinguistic Perspective Clevedon. Multilingual Matters

Fishman, J. A. 1990. What is reversing language shift (RLS) and how can it succeed? Journal of Multilingual and Multicultural Development $11(1 \& 2): 5-36$.

Gorter, D. 1987. Surveys of the Frisian language situation: Some considerations of research methods on language maintenance and language shift. International Journal of the Sociology of Language 68:41-56.

Hamel, R. E. 1997. Language conflict and language shift: A sociolinguistic framework for linguistic human rights. International Journal of the Sociology of Language, 127, 105- Hornberger, N. H. (1997). Literacy, language maintenance, and linguistic human rights: Three telling cases. International Journal of the Sociology of Language, 127, 87- 103.

Pandharipande, R.1992 Language Shift in India: Issues and Implications. In Fase, W. Jaspaert, K Kroon, S. (eds.), Maintenance and loss of minority languages, Amsterdam-Philadelphia, John BenjaminsPublishing Company.

Paulston, C. B. 1992. Linguistic Minorities and Language Policies: Four Case Studies. In Fase, W. Jaspaert, K Kroon, S. (eds.), Maintenance and loss of minority languages, Amsterdam-Philadelphia, John Benjamins Publishing Company.

Pandharipande, R. 1992. Language shift in India. In Maintenance and loss of minoritylanguages, ed. W. Fase, K. Jaspaert and S. Kroon, 255-276. Amsterdam: John Benjamins. 
Pankhurst, R. and Gerard, D. 1996. Ethiopia photographed. London: Kegan Paul International.

Rahman, F., Akhmar, A. M., Amir, M., \& Tammasse. (2019). The Practice of Local Wisdom of Kajang People to Save Forests and Biodiversity: A Cultural-Based Analysis. \{IOP\} Conference Series: Earth and Environmental Science, 270, 12038. https://doi.org/10.1088/1755$\underline{1315 / 270 / 1 / 012038}$

Sedlak, P. A. S. and National Taiwan Normal University English Research Institute. 1975. Generational language shift and linguistic diversity measures: A Kenya case. Studies in African Linguistics 6(1):65-76.

Veltman, C. 1991. Theory and method in the study of language shift. In language and ethnicity, ed. J. R. Dow, 145-167. Amsterdam: John Benjamins. 